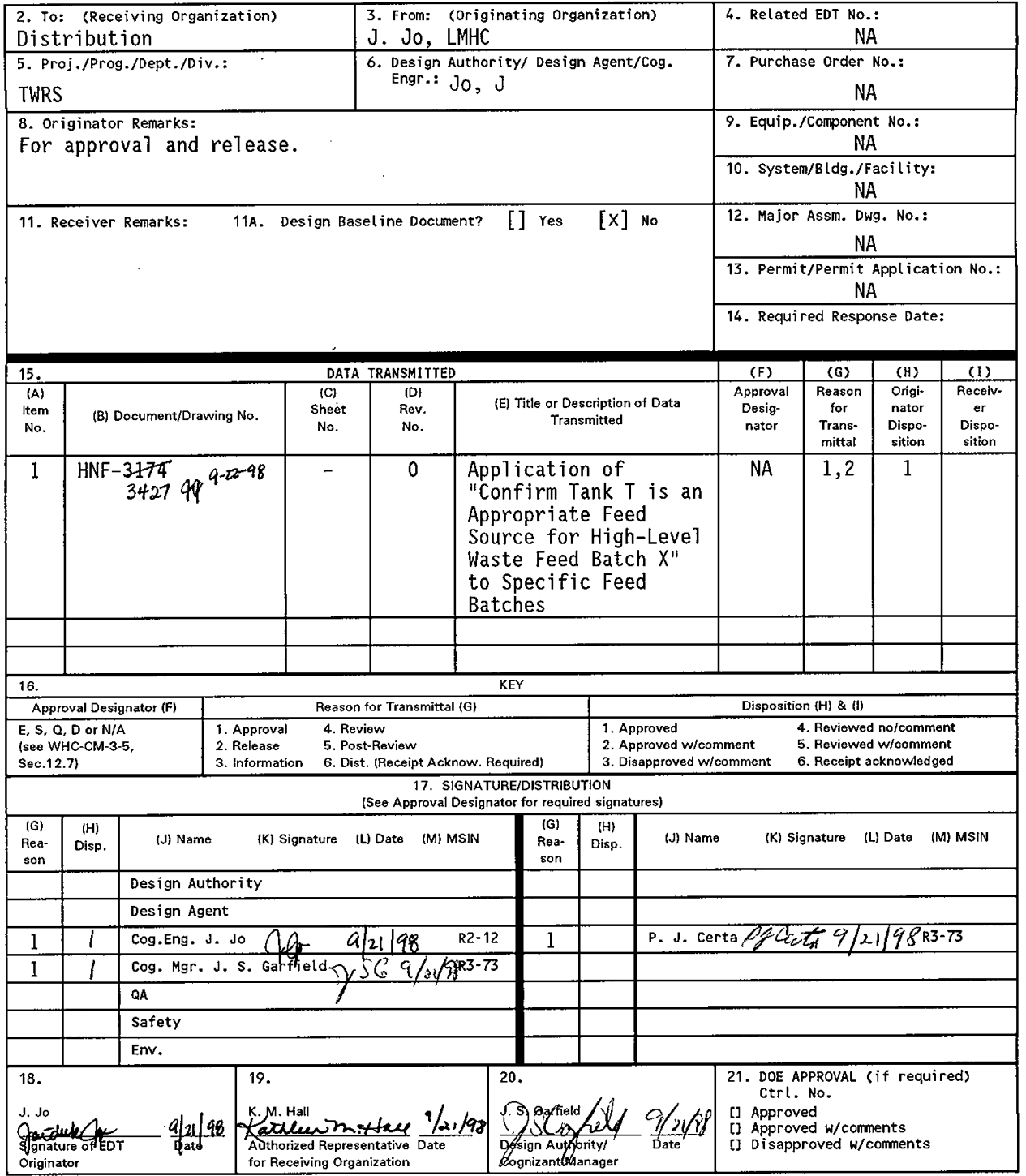


HNF-3174, Rev. 0

\section{Application of "Confirm Tank $T$ is an Appropriate Feed Source for High-Level Waste Feed Batch X" to Specific Feed Batches}

J. Jo

Lockheed Martin Hanford Corporation, Richland, WA 99352

U.S. Department of Energy Contract DE-AC06-96RL13200

EDT/ECN: 624561

Org Code: $8 \mathrm{C} 451$

B\&R Code: EW3130010

UC: 721

Charge Code: D2D28

Tota1 Pages: $4 /$

Key Words: Data quality objectives, DQO, PSDQO, TWRS

Abstract: This document addresses the characterization needs of tanks as set forth in the Data Quality Objectives for TWRS Privatization Phase I: Confirm Tank $T$ is an Appropriate Feed Source for High-Leve7 Waste Feed Batch X (Crawford et a1. 1998).

TRADEMARK DISCLAIMER. Reference herein to any specific commercial product, process, or service by trade name, traciemark, manufacturer, or otherwise, does not necessarily constitute or imply its endorsement, recommendation, or favoring by the United States Government or any agency thereof or its contractors or subcontractors.

Printed in the United States of America. To obtain copies of this document, contact: Document Control Services, P.0. Box 950, Mailstop H6-08, Richland WA 99352, Phone (509) 372-2420; Fax (509) 376-4989.
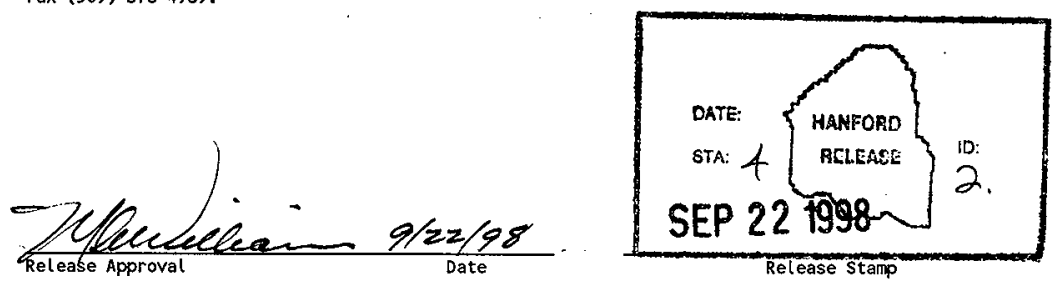


\title{
APPLICATION OF "CONFIRM TANK T IS AN APPROPRIATE FEED SOURCE FOR HIGH-LEVEL WASTE FEED BATCH X" TO SPECIFIC FEED BATCHES
}

September 1998

\author{
J. Jo \\ Lockheed Martin Hanford Corporation \\ Richland, Washington
}

Prepared for

U.S. Department of Energy

Richland, Washington 
HNF-3427

Revision 0

This page intentionally left blank. 


\section{CONTENTS}

1.0 INTRODUCTION $\ldots \ldots \ldots \ldots \ldots \ldots \ldots \ldots \ldots \ldots \ldots \ldots \ldots \ldots \ldots \ldots$

2.0 APPROACH $\ldots \ldots \ldots \ldots \ldots \ldots \ldots \ldots \ldots \ldots \ldots \ldots \ldots \ldots \ldots \ldots \ldots \ldots \ldots \ldots$

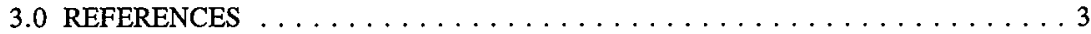

ADDENDUM 1 - TANK 241-AZ-101 /BATCHES 1 AND $2 \ldots \ldots \ldots$ Addendum-1 ADDENDUM 2 - TANK 241-AZ-102/BATCHES 3, 4, 5, AND $6 \ldots \ldots$ Addendum-2

\section{LIST OF FIGURES}

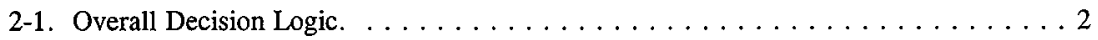


HNF-3427

Revision 0

\section{LIST OF TERMS}

DQO Data Quality Objective

ESP 1 Environmental Simulation Program

HLW High-level waste

PSDQO Problem-Specific Data Quality Objectives

TSAP Tank Sampling and Analysis Plan

TWRS Tank Waste Remediation System

${ }^{1} \mathrm{ESP}$ is a trademark of OLI Systems, Inc. 


\section{APPLICATION OF "CONFIRM TANK T IS AN APPROPRIATE FEED SOURCE FOR HIGH-LEVEL WASTE FEED BATCH $X^{n}$ TO SPECIFIC FEED BATCHES}

\subsection{INTRODUCTION}

This document addresses the characterization needs of tanks as set forth in the Data Quality Objectives for TWRS Privatization Phase I: Confirm Tank T is an Appropriate Feed Source for High-Level Waste Feed Batch X (Crawford et al. 1998).

The primary purpose of this document is to collect existing data and identify the data needed to determine whether or not the feed source(s) are appropriate for a specific batch. To answer these questions, the existing tank data must be collected and a detailed review performed.

If the existing data are insufficient to complete a full comparison, additional data must be obtained from the feed source(s). Additional information requirements need to be identified and formally documented, then the source tank waste must be sampled or resampled and analyzed. Once the additional data are obtained, the data shall be incorporated into the existing database for the source tank and a reevaluation of the data against the Data Quality Objective (DQO) must be made.

\subsection{APPROACH}

The Tank Waste Retrieval Division has determined that a strategic and cost-effective way to identify the data needed for high-level waste (HLW) feed delivery is to define those data needs on a batch-by-batch basis using the DQO process. The overall decision logic is shown schematically in Figure 2-1.

The first step in identifying the data need is for the Tank Waste Retrieval Division to translate its operating scenario into a series of process steps (essentially a process flowsheet) that clearly defines the waste to which each element of the decision rule applies. Alternatives to the baseline operating scenario may also be addressed.

The second step is to apply the decision rule to each group of operating scenario activities that constitute a source of waste feed going to the waste feed staging tanks. 
HNF-3427

Revision 0

Figure 2-1. Overall Decision Logic.

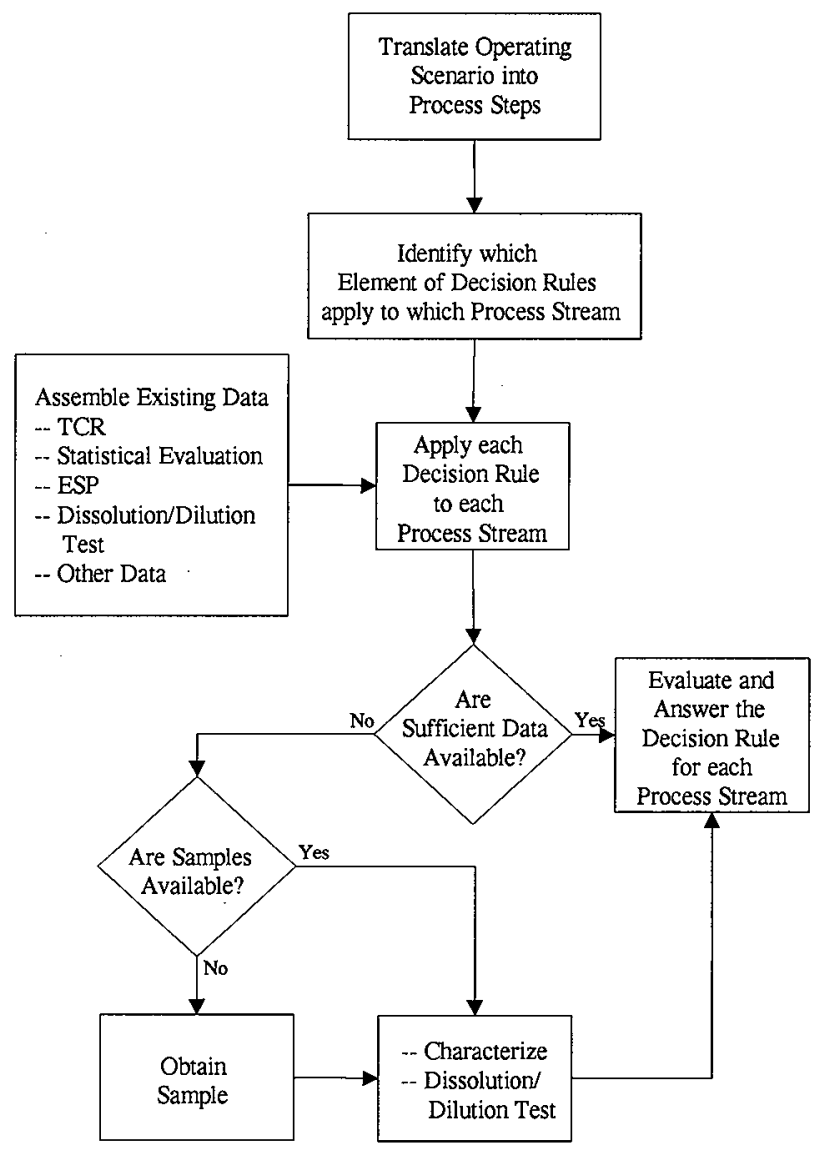

ESP $^{1}=$ Environmental Simulation Program

TCR $=$ Tank Characterization Report

${ }^{1}$ ESP is a trademark of OLI Systems, Inc. 
The third step is to determine if the data needed to address each element can be supplied by or approximated with existing (Best-Basis Inventory) or new characterization data on the waste, statistical evaluations, mathematical or process models such as Environmental Simulation Program (ESP ${ }^{1}$ ), or by process testing on existing or new samples including dissolution/dilution testing.

If the existing data are insufficient to complete a full evaluation, additional data must be obtained from Tank $\mathrm{T}$. The missing information needs to be identified and formally documented in this document. Unless sufficient archived samples can be found, Tank $T$ waste must be sampled and analyzed. Once these data are obtained, they shall be compiled into the existing database for Tank $T$ and a reevaluation of the data must be made.

\subsection{REFERENCES}

Crawford, T. W., R. D. Schreiber, and J. Jo, 1998, Data Quality Objectives for TWRS Privatization Phase I: Confirm Tank $T$ is an Appropriate Feed source for High-Level Waste Feed Batch X, HNF-1558 Rev. 0 (Draft), Numatec Hanford Corporation, Richland, Washington.

${ }^{1}$ ESP is a trademark of OLI Systems, Inc. 
HNF-3427

Revision 0

This page intentionally left blank. 


\section{ADDENDUM 1}

\section{APPLICATION OF}

\section{"CONFIRM TANK T IS AN APPROPRIATE FEED SOURCE FOR HIGH-LEVEL WASTE FEED BATCH $X "$}

TO

241-AZ-101 / BATCHES 1 AND 2 
HNF-3427

Revision 0

This page intentionally left blank.

Addendum 1-2 
HNF-3427

Revision 0

CONTENTS

1.0 INTRODUCTION $\ldots \ldots \ldots \ldots \ldots \ldots \ldots \ldots \ldots \ldots \ldots \ldots \ldots \ldots$ Addendum $1-5$

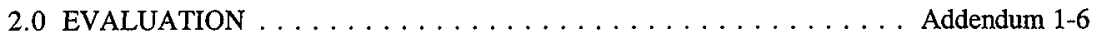

2.1 BASE CASE OPERATING SCENARIO $\ldots \ldots \ldots \ldots \ldots$ Addendum 1-6

3.0 REFERENCES $\ldots \ldots \ldots \ldots \ldots \ldots \ldots \ldots \ldots \ldots \ldots \ldots \ldots \ldots \ldots$ Addendum $1-16$

\section{LIST OF TABLES}

1. Evaluation of the Base Case Operating Scenario. . . . . . . . . Addendum 1-9

2. Summary of Information Needs. $\ldots \ldots \ldots \ldots \ldots \ldots \ldots$ Addendum 1-14 
HNF-3427

Revision 0

\section{LIST OF TERMS}

$\begin{array}{ll}\text { AGA } & \text { Alternatives generation and analysis } \\ \text { BBI } & \text { Best-Basis Inventory } \\ \text { DOE } & \text { U.S. Department of Energy } \\ \text { DST } & \text { Double-shell tank } \\ \text { ESP } & \text { Environmental Simulation Program } \\ \text { HLW } & \text { High-Level Waste } \\ \text { IC } & \text { Ion chromatography } \\ \text { ICD } & \text { Interface Control Document } \\ \text { ICP } & \text { Inductively coupled plasma } \\ \text { LAW } & \text { Low-Activity Waste } \\ \text { M } & \text { Molar (gmoles/liter) } \\ \text { M\&I } & \text { Management and Integration } \\ \text { NVO } & \text { Non-volatile oxides } \\ \text { PHMC } & \text { Project Hanford Management Contract(or) } \\ \text { PMBS } & \text { Project Master Baseline Schedule } \\ \text { PSDQO } & \text { Problem-Specific Data Quality Objectives } \\ \text { RL } & \text { U.S. Department of Energy-Richland Operations Office } \\ \text { TANK T } & \text { Refers to the contents from one tank, multiple tanks, or portions of one or } \\ & \text { more tanks that will be used to prepare a feed batch } \\ \text { TOC } & \text { Total Organic Carbon } \\ \text { TWRS } & \text { Tank Waste Remediation System } \\ \text { TWRSO\&UP } & \text { Tank Waste Remediation System Operation and Utilization Plan } \\ \text { URSILLA } & \text { Ultrasonic interface level analyzers } \\ \text { USQ } & \text { Unreviewed Safety Question } \\ \text { WIT } & \text { Waste Disposal Integration Team } \\ \end{array}$


HNF-3427

Revision 0

\section{APPLICATION OF "CONFIRM TANK T IS AN APPROPRIATE FEED SOURCE FOR HIGH-LEVEL WASTE FEED BATCH X" TO 241-AZ-101 / BATCHES 1 AND 2}

\subsection{INTRODUCTION}

This addendum applies Revision 0 of "Confirm Tank $\mathrm{T}$ is an Appropriate Feed Source for High-Level Waste Feed Batch X" problem-specific data quality objectives (PSDQO) to tank 241-AZ-101 / Batches 1 and 2.

This application of PSDQO-02 (Crawford et al. 1998) describes the Base Case Operating Scenario, which pretreats the waste in tank 241-AZ-101 prior to transfer to the Privatization Contractor.

There is one base case operating scenario for 241-AZ-101 whose elements are described. Table 1 in Section 2.0 contains specific information specific to 241-AZ-101 addressing all elements in Section 6 of the PSDQO on Confirm Tank T for HLW. Table 2 in Section 2.0 covers the specific new data required by the waste feed delivery program to confirm that 241-AZ-101 is an appropriate feed source. 
HNF-3427

Revision 0

\subsection{EVALUATION}

\subsection{BASE CASE OPERATING SCENARIO}

Translate the operating scenario into a series of process steps.

The base case operating scenario from the Waste Feed Delivery Technical Basis, Volume II, Waste Feed Delivery Flowsheet (Papp 1998) includes the following steps to make up Batches 1 and 2:

\section{Step Description}

(1) Decant Initial Supernate. Decant the supernate to the appropriate DST. The supernate from 241-AZ-101 will be transferred to 241-AY-101. The solids content will be monitored using a turbidity meter or other in-line instrument. Stop the decant when the solids content reaches a predefined limit, indicating that the supernate/settled solids interface has been reached.

The decant transfer pump will be capable of decanting liquid with a variable depth inlet that is adjustable from the tank's maximum operating level to within $0.25 \mathrm{~m}(10 \mathrm{in}$.) of the tank sludge level. The pump inlet height will be adjustable while pumping. The inlet height will be controlled to minimize entrainment and pickup of solids in the decanted liquid. The decant transfer pump will not be used during mixer pump operation and it will be designed so that it is not damaged by mixer pump operation. The transfer system will be instrumented for flow, pressure, density, viscosity, and turbidity as well as appropriate motor control instrumentation.

(2) Add Sludge Wash Solution. Add heated sludge wash solution to the slurry in 241-AZ-101. The wash solution $(2 M, 0.32 M \mathrm{NaOH}$ and raw water for the first, second, and third washes respectively) is added in a 3:4, 5:4, and 5:4 (for the first, second, and third washes respectively) dilution ratio with the settled solids volume. Wash solutions will be added through a nozzle in a tank riser and will dump into the vapor space. Alternatively, an "enhanced" sludge washing solution may be used to remove additional aluminum from the sludge. The enhanced sludge washing will be performed by adding a more concentrated $\mathrm{NaOH}$ solution. The washing will be enhanced by heating the slurry, through mixer pump operation, and use of preheated wash solution.

(3) Mix Feed. Mix the tank contents using the mixer pumps, which also adds heat to the slurry. This activity is assumed to take 5 days, at which time the slurry is at $80^{\circ} \mathrm{C}$.

(4) Take Process Control Samples. Process control samples are assumed to be three grab samples taken at different depths from a single riser. Samples are taken as soon as possible after the mixer pumps are turned off. The sample results are used to evaluate progress of the sludge washing and analyze for key parameters that are identified as 
"borderline" with respect to Envelope D. Decisions to be made are whether to proceed with feed qualification sampling, decant a portion or all of the wash liquor, perform another sludge washing cycle, or adjust the feed composition to maintain the feed within Envelope D.

(5) Analyze Process Control Samples. The laboratory analyses are assumed to take 2 weeks to complete and report. Analyses will likely include inductively coupled plasma (ICP) and ion chromatography (IC) analysis of dissolved solids, bulk density, pH, and $\%$ solids.

(6) Evaluate Sample Data. If the samples indicate that the sludge may not be within specification, evaluate options for further pretreatment. Modeling may be used to evaluate the effectiveness of further pretreatment. Pretreatment options include further sludge washing, adjusting the feed by adding glass formers such as $\mathrm{SiO}_{2}$ and/or $\mathrm{NaO}$. Blending with sludge from another double-shell tank (DST) is also possible depending on the availability of a retrieval system in the other DST.

(7) Settle Solids. The mixer pumps were turned off to allow process control sampling (step 4). The solids are allowed to settle prior to further processing. The progress of the solids settling will be monitored using ultrasonic interface level analyzers (URSILLA) and/or gamma profiles in drywells. Settling is assumed to require 30 days.

(8) Decant Supernate. Decant the supernate (wash solution) to the appropriate storage DST. The supernate from 241-AZ-101 is transferred to tank 241-AW-105 (this is the current tank, but that may change). This activity is the same as step 1 and would be controlled similarly.

The planned number of sludge washing cycles are three for 241-AZ-101. Each sludge wash cycle is a repeat of steps $2-8$.

(9) Adjust Feed (Optional). If selected in step 6 and approved by DOE, adjust the feed by chemical shimming or blending.

(10) Add Transfer Solution. An inhibited-water solution is added to 241-AZ-101 to dilute the solids so the slurry concentration is between $25 \mathrm{~g} / \mathrm{L}$ and $100 \mathrm{~g} / \mathrm{L}$ waste oxides. This dilution should meet waste transfer requirements.

(11) Mix Feed. The mixer pumps are used to mix the slurry in 241-AZ-101. This step should be relatively quick; requiring a few hours to a few days of mixing.

(12) Sample Staged Feed. Feed qualification sampling will be covered in Data Quality Objectives for TWRS Privatization Phase 1: High-Level Waste Feed Delivery Transfer to Private Contractors (PSDQO-10) (Crawford 1998). 
Define the waste that applies to each element in the decision rule.

Element 1, Envelope Requirements (Composition and Physical Properties): the waste to be used to provide Batches 1 and 2 is pretreated sludge from tank 241-AZ-101. The envelope limits apply to each batch transferred to the private contractor (solids and liquid). The waste currently residing in tank 241-AZ-101 has not been pretreated, and also contains supernatant which will be used for LAW Envelope B feed. The Envelope B feed must be separated from the sludge prior to pretreatment and staged into tank 241-AY-101. The ability to comply with the Waste Envelope D feed specifications is based on projections, using sample and process test data.

Element 2, Quantity Requirements: This requirement applies to the size of each batch of HLW feed (mass of non-volatile oxides excluding sodium and silicon) delivered from 241-AZ-101 to the Privatization Contractor.

Element 3, Pretreatment Process Chemistry Requirements: These requirements apply to the equilibrium distribution of chemical species (i.e., the contract envelope analytes) between the solid and liquid phases, contact time and temperature required to achieve chemical equilibrium, and determination of the number and type of sludge washes required to make desired feed.

Element 4, Transfer Requirements: Transfer requirements apply to a whole tank composite of the waste in 241-AZ-101 after pretreatment and after the addition of transfer solution.

Element 5, Miscellaneous Inputs: These inputs apply to the whole tank composition of 241-AZ-101 or to changes in the operating scenario that may be imposed in the future.

Evaluate existing data and determine information needs.

Table 1 contains what data are available and needed to establish that 241-AZ-101 is appropriate for meeting Envelope D feed requirements. The elements for making this . determination are found in Section 6 of the PSDQO for Confirm Tank T for HLW. The information needs are summarized in Table 2. 
Table 1. Evaluation of the Base Case Operating Scenario. (5 Sheets)

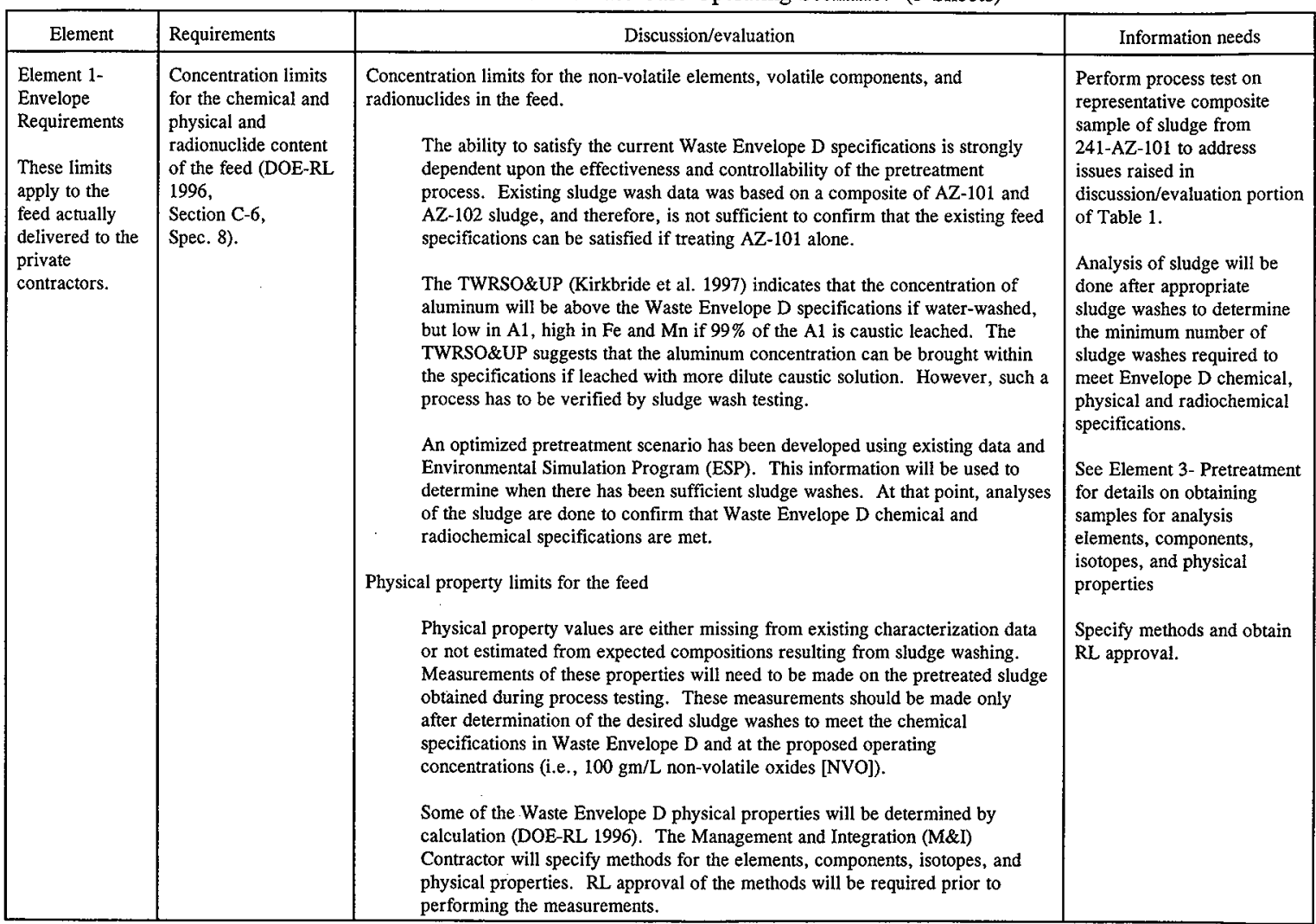


Table 1. Evaluation of the Base Case Operating Scenario. (5 Sheets)

\begin{tabular}{|c|c|c|c|}
\hline Element & Requirements & Discussion/evaluation & Information needs \\
\hline $\begin{array}{l}\text { Element 2- } \\
\text { Quantity } \\
\text { Requirements }\end{array}$ & $\begin{array}{l}\text { Batch size constraint } \\
\text { (from the contracts } \\
\text { [DOE-RL 1996]) } \\
\text { z } 5 \text { MT Mass of } \\
\text { non-volatile oxides } \\
\text { excluding sodium and } \\
\text { silicon }\end{array}$ & $\begin{array}{l}\text { Contract Batch Size Requirement } \\
\text { The current inventory of } 241-\mathrm{AZ}-101 \text { indicates approximately } 96.4 \mathrm{MT} \text { of } \\
\text { HLW feed. The mixer pumps are expected to be capable of mobilizing } \\
90 \text { percent of the waste in } 241-\mathrm{AZ}-101 \text {. Therefore, the requirement of a } \\
\text { minimum of } 5 \mathrm{MT} \text { of HLW feed for the initial batch can be met. } \\
\text { PHMC Targeted Batch Size } \\
\text { Assuming the Privatization contractor has the capacity to receive a maximum } \\
\text { batch of } 587 \mathrm{~kL}(155 \mathrm{kgal}), \text { plus two line volumes of flush solution estimated to } \\
\text { be } 60 \mathrm{~kL}(13 \mathrm{kgal}) \text { the PHMC intends to deliver that HLW feed at the } \\
\text { maximum concentration (subject to waste transfer system limitations) of } \\
100 \mathrm{~g} \text { NVO/L. A measurement of the sludge fraction mobilized in } 241-\mathrm{AZ}-101 \\
\text { is needed during the W-151 mixer pump test. This test will verify that at least } \\
90 \text { percent of the sludge can be mobilized. To obtain this concentration, the } \\
\text { slurry concentration will have to be diluted. There should be no dilution } \\
\text { difficulties (See Element } 4 \text { below). Based on this concentration, the pretreated } \\
\text { sludge } 241-\mathrm{AZ}-101 \mathrm{can} \text { be delivered in } 2 \text { equal sized batches of } 43.4 \mathrm{MT} \text {, } \\
\text { which is much higher than the } 5 \mathrm{MT} \text { minimum initial batch size. }\end{array}$ & $\begin{array}{l}\text { Expectation is that there will } \\
\text { be no difficulty in achieving } \\
\text { the desired } 1,100 \mathrm{~g} \mathrm{NVO} / \mathrm{L} \\
\text { slurry concentration. }\end{array}$ \\
\hline
\end{tabular}


Table 1. Evaluation of the Base Case Operating Scenario. (5 Sheets)

\begin{tabular}{|c|c|c|c|}
\hline Element & Requirements & Discussion/evaluation & Information needs \\
\hline $\begin{array}{l}\text { Element 3- } \\
\text { Pretreatment } \\
\text { Process } \\
\text { Chemistry } \\
\text { Requirements }\end{array}$ & $\begin{array}{l}\text { Type and number of } \\
\text { sludge washes to } \\
\text { meet Waste Envelope } \\
\text { D specifications }\end{array}$ & $\begin{array}{l}\text { Confirmation the equilibrium distribution of chemical species } \\
\text { Current estimates of the HLW feed composition are projections based on } \\
\text { available process test and characterization data. Since the process tests were } \\
\text { conducted at different conditions for sludge washing, and the projections are } \\
\text { based only a theoretical chemical equilibrium models (i.e., ESP), process test } \\
\text { with representative samples is required. The objectives of such a test are to } \\
\text { determine the range of process parameters (e.g., temperature, } \\
\text { volume/concentration caustic, number of wash cycles, mixing time to reach } \\
\text { equilibrium, settling time), and efficiency in dissolution that would ensure } \\
\text { compliance with Waste Envelope D specifications in the pretreated sludge } \\
\text { product. } \\
\text { Based on Best-Basis Inventory (BBI) and ESP, sulfate needs to be removed } \\
\text { from interstitial fluid by washing to meet Waste Envelope D specifications. } \\
\text { Current estimates are that } 3 \text { washes are needed. If there is more solid sulfate } \\
\text { than expected, then removing sulfate to meet the Waste Envelope D } \\
\text { requirements need to be rethought. } \\
\text { In process testing, determine the rate of solids dissolution for comparison with } \\
\text { process time allotted. } \\
\text { Determine if caustic leaching is required to remove sufficient aluminum. } \\
\text { A process test is needed to verify the amount of aluminum A1 (and other minor } \\
\text { species) leached (dissolved) from the solids. This is required, because, some } \\
\text { degree of aluminum removal is required (based on the TWRSO\&UP), but not } \\
\text { too much. Too much removal could create problems with other cations (e.g., } \\
\text { Fe) that could limit the waste oxide loading. Current estimates of the amount } \\
\text { of A1 removal are based on limited process test data, and chemical equilibrium } \\
\text { models. Data need to be obtained to support carrying out an alternatives } \\
\text { generation and analysis (AGA) to determine how much A1 can be removed } \\
\text { before another cation limits the waste oxide loading. Also, establish the amount } \\
\text { of supernate to leave behind so the nitrate can enhance the ionic strength of } \\
\text { solution allowing more A1 to dissolve. }\end{array}$ & $\begin{array}{l}\text { Perform process test on } \\
\text { representative composite } \\
\text { sample of sludge from } \\
241-A Z-101 \text { to address } \\
\text { issues raised in } \\
\text { discussion/evaluation portion } \\
\text { of Table1. }\end{array}$ \\
\hline
\end{tabular}


Table 1. Evaluation of the Base Case Operating Scenario. (5 Sheets)

\begin{tabular}{|c|c|c|c|}
\hline Element & Requirements & Discussion/evaluation & Information needs \\
\hline $\begin{array}{l}\text { Element 3- } \\
\text { Pretreatment } \\
\text { Process } \\
\text { Chemistry } \\
\text { Requirements } \\
\text { (continued) }\end{array}$ & $\begin{array}{l}\text { Type and number of } \\
\text { sludge washes to } \\
\text { meet Waste } \\
\text { Envelope D } \\
\text { specifications } \\
\text { (continued) }\end{array}$ & $\begin{array}{l}\text { (Continued) } \\
\text { By adding Na as NaOH in the caustic leaching step, Mg and Ca will likely be } \\
\text { outside the Waste Envelope } \mathrm{D} \text { requirements. Sludge washes with "clean" water } \\
\text { are required to remove the added Na and to remove additional Al from the } \\
\text { interstitial fluid so Na will meet Waste Envelope D specifications. } \\
\text { These should be all the chemical issues related to waste processing. } \\
241-\mathrm{AZ}-101 \text { should meet all other Waste Envelope D chemical and } \\
\text { radiochemical requirements. } \\
\text { The potential also exists for poor settling due to the formation of gels. An } \\
\text { operating range for the process parameters needs to be determined, to avoid gel } \\
\text { formation. } \\
\text { Confirmation that the undissolved solids settle and that they settle in a reasonable } \\
\text { amount of time. } \\
\text { Existing settling rate data are based on laboratory, scale testing, with limited } \\
\text { applicability, due to wall effects in smaller vessels. The settling rates need to } \\
\text { be measured in a bench-scale settling column, to eliminate the wall effects, in } \\
\text { order to design the necessary equipment and to allocate the appropriate amount } \\
\text { of time required for waste feed processing. } \\
\text { Settling tests in } 241-\mathrm{AZ}-101 \text { will be performed as part of the W-151 mixer } \\
\text { pump tests. But, these tests may be complicated by the existing supernate. } \\
\text { Hence, the Waste Retrieval Program staff must determine the need for bench- } \\
\text { scale settling tests. } \\
\text { Confirmation that the baseline retrieval equipment that will be used to mobilize the } \\
\text { waste will work as planned. }\end{array}$ & \\
\hline
\end{tabular}


Table 1. Evaluation of the Base Case Operating Scenario. (5 Sheets)

\begin{tabular}{|c|c|c|c|}
\hline Element & Requirements & Discussion/evaluation & Information needs \\
\hline $\begin{array}{l}\text { Element 4- } \\
\text { Transfer } \\
\text { Requirements }\end{array}$ & $\begin{array}{l}\text { Confirm that the as- } \\
\text { retrieved waste } \\
\text { remains at or below } \\
\text { viscosity of } 10 \mathrm{cP} \text {, at } \\
\text { or below a } 1.5 \mathrm{SpG} \text {, } \\
\text { and at or below } \\
30 \text { percent solids by } \\
\text { volume during the } \\
\text { transfer to the private } \\
\text { contractor. } \\
\text { Confirm that the } \\
\text { selected dilution ratio } \\
\text { using inhibited water } \\
\text { will not form gibbsite } \\
\text { or cause components } \\
\text { in the slurry to } \\
\text { precipitate during the } \\
\text { transfer. }\end{array}$ & $\begin{array}{l}\text { There are limited data for estimating that: } \\
\text { 1) pretreated waste (i.e., after sludge washing) will conform to the physical } \\
\text { measurements around which the transfer process was designed, } \\
\text { 2) the waste feed will remain within the Waste Envelope D during transfer, } \\
\text { 3) the dilution ratio will not cause excessive gels and other precipitates to form } \\
\text { in the transfer system. }\end{array}$ & $\begin{array}{l}\text { During process test, upon } \\
\text { completion of the desired } \\
\text { type and number of sludge } \\
\text { washes, obtain the } \\
\text { pretreated sludge sample } \\
\text { from } 241 \text {-AZ-101 to make } \\
\text { the required measurements. }\end{array}$ \\
\hline $\begin{array}{l}\text { Element 5- } \\
\text { Miscellaneous } \\
\text { Requirements }\end{array}$ & $\begin{array}{l}\text { Physical form of } \\
\text { Tank 241-AZ-101 } \\
\text { contents. } \\
\text { Shimming Batches } 1 \\
\text { and } 2\end{array}$ & $\begin{array}{l}\text { From Hodgson ( } 1995 \text { ), 241-AZ-101 consists of compositionally homogenous } \\
\text { supernate of approximately } 3,630 \mathrm{KL} \text {, a layer of soft sludge of approximately } 175 \mathrm{KL} \text {. } \\
\text { There is no heel/hard pan. } \\
\text { No shimming is anticipated. } \\
\text { No changes to applicable M\&I ICD requirements have been made to date. }\end{array}$ & $\begin{array}{l}\text { No further information is } \\
\text { needed. } \\
\text { No further information is } \\
\text { needed. } \\
\text { No further information is } \\
\text { needed at this time. }\end{array}$ \\
\hline
\end{tabular}


Table 2. Summary of Information Needs. (2 Sheets)

\begin{tabular}{|c|c|c|c|}
\hline Elements & Information needed & Planned resolution & Sample required \\
\hline $\begin{array}{l}\text { Element 1- } \\
\text { Envelope Requirements }\end{array}$ & $\begin{array}{l}\text { Upon performing the desired type and number } \\
\text { of sludge washes, perform analyses on the } \\
\text { resulting sludge to confirm that Waste } \\
\text { Envelope D specifications will likely be met } \\
\text { with } 241-\mathrm{AZ}-101 \text { contents. }\end{array}$ & $\begin{array}{l}\text { After process testing, analyze the } \\
\text { sludge washed sample for the Waste } \\
\text { Envelope D specifications. }\end{array}$ & $\begin{array}{l}300 \mathrm{gm} \text { samples taken from } \\
\text { Element } 3 .\end{array}$ \\
\hline $\begin{array}{l}\text { Element 2- } \\
\text { Quantity Requirements }\end{array}$ & Measurement of sludge fraction mobilized. & $\begin{array}{l}\text { After mixer pump operation and full } \\
\text { suspension of } 241-\text { AZ-101 solids, } \\
\text { analyze samples to determine percent } \\
\text { solids, particle density, and chemical } \\
\text { composition as function of height in } \\
\text { mixed siurry. }\end{array}$ & $\begin{array}{l}100 \mathrm{ml} \text { of } 241-\mathrm{AZ}-101 \text { slurry each } \\
\text { from } 10 \text { heights in tank. }\end{array}$ \\
\hline $\begin{array}{l}\text { Element 3- } \\
\text { Pretreatment Process } \\
\text { Chemistry Requirements }\end{array}$ & 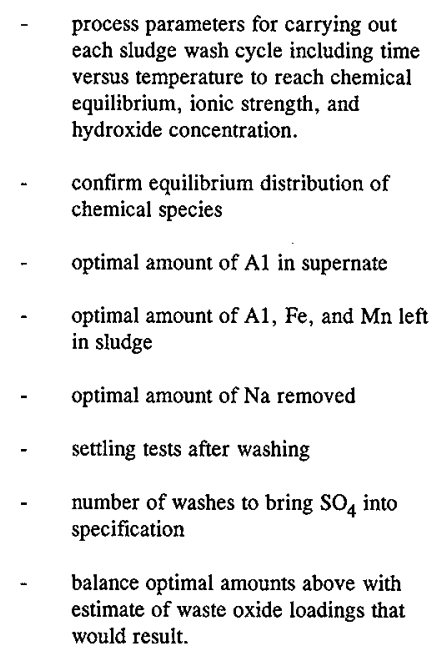 & $\begin{array}{l}\text { Perform process testing to establish } \\
\text { type and number of sludge washes. }\end{array}$ & $\begin{array}{l}\text { Solids fraction of slurry samples } \\
\text { taken in Element } 2 .\end{array}$ \\
\hline
\end{tabular}


Table 2. Summary of Information Needs. (2 Sheets)

\begin{tabular}{|l|l|l|l|}
\hline $\begin{array}{l}\text { Element 4- } \\
\text { Transfer Requirements }\end{array}$ & $\begin{array}{l}\text { Confirm that waste meets transfer } \\
\text { requirements. }\end{array}$ & $\begin{array}{l}\text { During process test, confirm that } \\
\text { supernate and slurry meet viscosity, } \\
\text { SpG, percent solids, transfer } \\
\text { requirements. Confirm that remain } \\
\text { within Envelope D physical } \\
\text { properties during transfer. }\end{array}$ & $\begin{array}{l}\text { Performed as part of process test for } \\
\text { Element 3, above. }\end{array}$ \\
\hline $\begin{array}{l}\text { Element 5- } \\
\text { Miscellaneous Requirements }\end{array}$ & No new information needed. & No new information needed. & No new information needed. \\
\hline
\end{tabular}


HNF-3427

Revision 0

\subsection{REFERENCES}

Crawford, T. W., R. D. Schreiber, J. Jo, and A. F. Manuel (VECO), 1998, Data Quality Objectives for TWRS Privatization Phase 1: Confirm Tank $T$ is an Appropriate Feed Source for High-Level Waste Feed Batch X, HNF-1558 (PSDQO-02), Rev. 0, Lockheed Martin Hanford Corporation, Richland, Washington.

DOE-RL, 1996, TWRS Privatization, Contract Numbers DE-RP06-96RL13308 and 13309, U.S. Department of Energy, Richland, Washington.

Hodgson, K. M., 1995, Tank Characterization Report for Double-Shell Tank 241-AZ-101, Rev. 0, Westinghouse Hanford Company, Richland, Washington.

Kirkbride, R. A., G. K. Allen, P. J. Certa, A. F. Manuel, R. M. Orme, L. W. Shelton, E. J. Slaathaug, R. S. Wittman, G. T. MacLean, and D. L. Penwell, 1997, Tank Waste Remediation System Operation and Utilization Plan, HNF-SD-WM-SP-012, Rev. 0A, Vol. I and II, Numatec Hanford Corporation, Richland, Washington.

Papp, I. G., 1998, Waste Feed Delivery Technical Basis, Volume II, Waste Feed Delivery Flowsheet, HNF-1939, Vol. II, Rev. 0, Numatec Hanford Corporation, Richland, Washington. 
HNF-3427

Revision 0

\section{ADDENDUM 2}

\section{APPLICATION OF}

\section{"CONFIRM TANK T IS AN APPROPRIATE FEED SOURCE FOR HIGH-LEVEL WASTE FEED BATCH $X "$}

TO

241-AZ-102 / BATCHES 3, 4, 5, AND 6 
HNF-3427

Revision 0

This page intentionally left blank.

Addendum 2-2 
HNF-3427

Revision 0

CONTENTS

1.0 INTRODUCTION $\ldots \ldots \ldots \ldots \ldots \ldots \ldots \ldots \ldots \ldots \ldots \ldots \ldots \ldots \ldots \ldots \ldots$ Addendum $2-5$

2.0 EVALUATION $\ldots \ldots \ldots \ldots \ldots \ldots \ldots \ldots \ldots \ldots \ldots \ldots \ldots \ldots \ldots \ldots \ldots$ Addendum $2-6$

2.1 BASE CASE OPERATING SCENARIO $\ldots \ldots \ldots \ldots \ldots$ Addendum $2-6$

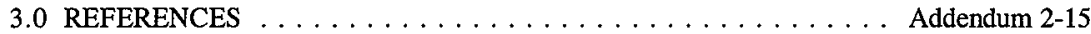

\section{LIST OF TABLES}

1. Evaluation of the Base Case Operating Scenario. . . . . . . . . . Addendum 2-9

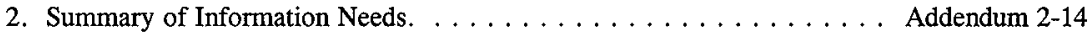




\section{LIST OF TERMS}

AGA

C

DOE-RL

DST

ESP

HLW

IC

ICP

LAW

$\underline{\mathrm{M}}$

M\&I

NVO

PHMC

PMBS

PSDQO

RL

TANK T

TOC

TWRS

TWRSO\&UP

URSILLA

USQ

WIT
Alternatives generation and analysis

centigrade

U.S. Department of Energy-Richland Operation

Double-shell tank

Environmental Simulation Program

High-Level Waste

Ion chromatography

Inductively coupled plasma

Low-Activity Waste

Molar (gmoles/liter)

Management and Integration

non-volatile oxides

Project Hanford Management Contract(or)

Project Master Baseline Schedule

Problem-Specific Data Quality Objectives

U.S. Department of Energy-Richland Operations

Refers to the contents from one tank, multiple tanks, or portions of one or more tanks that will be used to prepare a feed batch

Total Organic Carbon

Tank Waste Remediation System

Tank Waste Remediation System Operation and Utilization Plan

Ultrasonic interface level analyzers

Unreviewed Safety Question

Waste Disposal Integration Team 
HNF-3427

Revision 0

\section{APPLICATION OF "CONFIRM TANK T IS AN APPROPRIATE FEED SOURCE FOR HIGH-LEVEL WASTE FEED BATCH $X^{\prime \prime}$ \\ TO 241-AZ-102 / BATCHES 3, 4, 5, AND 6}

\subsection{INTRODUCTION}

This addendum applies Revision 0 of "Confirm Tank $\mathrm{T}$ is an Appropriate Feed Source for High-Level Waste Feed Batch X" problem-specific data quality objectives (PSDQO) to tank 241-AZ-102 / Batches 3, 4, 5, and 6.

This application of PSDQO-02 describes the Base Case Operating Scenario, which pretreats the waste in tank 241-AZ-102 prior to transfer to the Privatization Contractor.

There is one base case operating scenario for 241-AZ-102 whose elements are described. Table 1 in Section 2.0 contains information specific to 241-AZ-102 addressing all elements in Section 6 of the PSDQO on Confirm Tank T for HLW. Table 2 in Section 2.0 contains specific new data required by the waste feed delivery program to confirm that $241-\mathrm{AZ}-102$ is an appropriate feed source. 
HNF-3427

Revision 0

\subsection{EVALUATION}

\subsection{BASE CASE OPERATING SCENARIO}

Translate the operating scenario into a series of process steps.

The base case operating scenario from the Waste Feed Delivery Technical Basis, Volume II, Waste Feed Delivery Flowsheet (Papp 1998) includes the following steps to make up Batches 3, 4, 5 and 6:

\section{Step Description}

(1) Decant Initial Supernate. Decant the supernate to the appropriate DST. The supernate from 241-AZ-102 will be transferred to 241-AY-101. The solids content will be monitored using a turbidity meter or other in-line instrument. Stop the decant when the solids content reaches a predefined limit, indicating that the supernate/settled solids interface has been reached.

The decant transfer pump will be capable of decanting liquid with a variable depth inlet which is adjustable from the tank's maximum operating level to within $0.25 \mathrm{~m}$ (10 in.) of the tank sludge level. The pump inlet height will be adjustable while pumping. The inlet height will be controlled to minimize entrainment and pickup of solids in the decanted liquid. The decant transfer pump will not be used during mixer pump operation and it will be designed so that it is not damaged by mixer pump operation. The transfer system will be instrumented for flow, pressure, density, viscosity, and turbidity as well as appropriate motor control instrumentation.

(2) Add Sludge Wash Solution. Add heated sludge wash solution to the slurry in 241-AZ-102. The wash solution ( $2 M, 0.32 M \mathrm{NaOH}$ and raw water) is added in a $3: 4$, $5: 4$, and 5:4 dilution ratio (for the first, second, and third washes respectively) with the settled solids volume. Wash solutions will be added through a nozzle in a tank riser and will dump into the vapor space. Alternatively, an "enhanced" sludge washing solution may be used to remove additional aluminum from the sludge. The enhanced sludge washing will be performed by adding a more concentrated $\mathrm{NaOH}$ solution. The washing will be enhanced by heating the slurry, through mixer pump operation, and use of preheated wash solution.

(3) Mix Feed. Mix the tank contents using the mixer pumps, which also adds heat to the slurry. This activity is assumed to take 5 days, at which time the slurry is at $80^{\circ} \mathrm{C}$.

(4) Take Process Control Samples. Process control samples are assumed to be three grab samples taken at different depths from a single riser. Samples are taken as soon as possible after the mixer pumps are turned off. The sample results are used to evaluate progress of the sludge washing and analyze for key parameters that are identified as 
"borderline" with respect to Envelope D. Decisions to be made are whether to proceed with feed qualification sampling, decant a portion or all of the wash liquor, perform another sludge washing cycle, or adjust the feed composition to maintain the feed within Envelope D.

(5) Analyze Process Control Samples. The laboratory analyses are assumed to take 2 weeks to complete and report. Analyses will likely include inductively coupled plasma (ICP) and ion chromatography (IC) analysis, dissolved solids, bulk density, $\mathrm{pH}$, and \% solids.

(6) Evaluate Sample Data. If the samples indicate the sludge may not be within specification, evaluate options for further pretreatment. Modeling may be used to evaluate the effectiveness of further pretreatment. Pretreatment options include further sludge washing, adjusting the feed by adding glass formers such as $\mathrm{SiO}_{2}$ and/or $\mathrm{NaO}$. Blending with sludge from another double-shell tank (DST) is also possible depending on the availability of a retrieval system in the other DST.

(7) Settle Solids. The mixer pumps were turned off to allow process control sampling (step 4). The solids are allowed to settle prior to further processing. The progress of the solids settling will be monitored using ultrasonic interface level analyzers (URSILLA) and/or gamma profiles in drywells. Settling is assumed to require 30 days.

(8) Decant Supernate. Decant the supernate (wash solution) to the appropriate storage DST. The supernate from 241-AZ-102 is transferred to tank 241-AN-105 (this is the current tank, but that may change). This activity is similar to step 1 and would be controlled similarly.

The planned number of sludge washing cycles are three for 241-AZ-102. Each sludge wash cycle is a repeat of steps 2-8.

(9) Adjust Feed (Optional). If selected in step 6 and approved by DOE, adjust the feed by chemical shimming or blending.

(10) Add Transfer Solution. An inhibited-water solution is added to 241-AZ-102 to dilute the solids so the slurry concentration is between $25 \mathrm{~g} / \mathrm{L}$ and $100 \mathrm{~g} / \mathrm{L}$ waste oxides. This dilution should meet waste transfer requirements.

(11) Mix Feed. The mixer pumps are used to mix the slurry in 241-AZ-102. This step should be relatively quick; requiring a few hours to a few days of mixing.

(12) Sample Staged Feed. Feed qualification sampling will be discussed in Data Quality Objectives for TWRS Privatization Phase 1: High-Level Waste Feed Delivery Transfer to Private Contractors (PSDQO-10) (Crawford 1998). 
HNF-3427

Revision 0

Define the waste that applies to each element in the decision rule.

Element 1, Envelope Requirements (Composition and Physical Properties): the waste used to provide Batches $3,4,5$, and 6 is pretreated sludge from tank 241-AZ-102. The envelope limits apply to each batch transferred to the private contractor (solids and liquid). The waste currently residing in tank $241-\mathrm{AZ}-102$ has not been pretreated, and also contains supernatant which will be used for LAW Envelope B feed. The Envelope B feed must be separated from the sludge prior to pretreatment and staged into tank 241-AY-101. The ability to comply with the Waste Envelope D feed specifications is based on projections, using sample and process test data.

Element 2, Quantity Requirements: This requirement applies to the size of each batch of HLW feed (mass of non-volatile oxides excluding sodium and silicon) delivered from 241-AZ-102 to the Privatization Contractor.

Element 3, Pretreatment Process Chemistry Requirements: These requirements apply to the equilibrium distribution of chemical species (i.e., the contract envelope analytes) between the solid and liquid phases, contact time and temperature required to achieve chemical equilibrium, and determination of the number and type of sludge washes required to make desired feed.

Element 4, Transfer Requirements: Transfer requirements apply to a whole tank composite of the waste in 241-AZ-102 after pretreatment and after the addition of transfer solution.

Element 5, Miscellaneous Inputs: These inputs apply to the whole tank composition of 241-AZ-101 or to changes in the operating scenario that may be imposed in the future.

Evaluate existing data and determine information needs.

Table 1 contains what data are available and needed to establish 241-AZ-102 as appropriate for meeting Envelope D feed requirements. The elements for making this determination are found in Section 6 of the PSDQO for Confirm Tank T for HLW. The information needs are summarized in Table 2. 
Table 1. Evaluation of the Base Case Operating Scenario. (5 Sheets)

\begin{tabular}{|c|c|c|c|}
\hline Element & Requirements & Discussion/evaluation & Information needs \\
\hline
\end{tabular}


Table 1. Evaluation of the Base Case Operating Scenario. (5 Sheets)

\begin{tabular}{|c|c|c|c|}
\hline Element & Requirements & Discussion/evaluation & Information needs \\
\hline $\begin{array}{l}\text { Element 2- } \\
\text { Quantity } \\
\text { Requirements }\end{array}$ & $\begin{array}{l}\text { Batch size constraint } \\
\text { (from the contracts } \\
\text { [DOE-RL 1996]) } \\
\text { 2 } 5 \text { MT Mass of } \\
\text { non-volatile oxides } \\
\text { excluding sodium and } \\
\text { silicon }\end{array}$ & $\begin{array}{l}\text { Contract Batch Size Requirement } \\
\text { The current inventory of } 241-\mathrm{AZ}-102 \text { indicates approximately } 160 \mathrm{MT} \text { of HLW } \\
\text { feed. The mixer pumps are expected to be capable of mobilizing } 60 \text { percent of } \\
\text { the waste in } 241-\mathrm{AZ}-102 \text {. Therefore, the requirement of a minimum of } 5 \mathrm{MT} \\
\text { of HLW feed for the initial batch can be met. } \\
\text { PHMC Targeted Batch Size } \\
\text { Assuming the Privatization contractor has the capacity to receive a maximum } \\
\text { batch of } 587 \mathrm{~kL} \text { (155 kgal) plus four flush solution estimated to be } 60 \mathrm{~kL} \text { (13 } \\
\text { kgal), the PHMC intends to deliver that HLW feed at the maximum } \\
\text { concentration (subject to waste transfer system limitations) of } 100 \mathrm{~g} \mathrm{NVO/L} \text {. } \\
\text { Based on this concentration, the pretreated sludge } 241-\mathrm{AZ}-102 \mathrm{can} \text { be delivered } \\
\text { in } 4 \text { equal sized batches of } 24 \mathrm{MT} \text {, which is much higher than the } 5 \mathrm{MT} \\
\text { minimum initial batch size. }\end{array}$ & $\begin{array}{l}\text { Expectation is that there will } \\
\text { be no difficuity in achieving } \\
\text { the desired } 100 \mathrm{~g} \mathrm{NVO} / \mathrm{L} \\
\text { slurry concentration. }\end{array}$ \\
\hline
\end{tabular}


Table 1. Evaluation of the Base Case Operating Scenario. (5 Sheets)

\begin{tabular}{|c|c|c|c|}
\hline Element & Requirements & Discussion/evaluation & Information needs \\
\hline $\begin{array}{l}\text { Element 3- } \\
\text { Pretreatment } \\
\text { Process } \\
\text { Chemistry } \\
\text { Requirements }\end{array}$ & $\begin{array}{l}\text { Type and number of } \\
\text { sludge washes to } \\
\text { meet Waste Envelope } \\
\text { D specifications }\end{array}$ & $\begin{array}{l}\text { Confirm the equilibrium distribution of chemical species } \\
\text { Current estimates of the HLW feed composition are projections based on } \\
\text { available process test and characterization data. Since the process tests were } \\
\text { conducted at different conditions for sludge washing, and the projections are } \\
\text { based only on theoretical chemical equilibrium models (i.e., ESP), process tests } \\
\text { with representative samples is required. The objectives of such a test are to } \\
\text { determine the range of process parameters (e.g., temperature, } \\
\text { volume/concentration caustic, number of wash cycles, mixing time to reach } \\
\text { equilibrium, settling time), and efficiency in dissolution that would ensure } \\
\text { compliance with Waste Envelope D specifications in the pretreated sludge } \\
\text { product. } \\
\text { In process testing, determine the rate of solids dissolution for comparison with } \\
\text { process time allotted. } \\
\text { Determine if caustic leaching is required to remove sufficient aluminum. } \\
\text { A process test is needed to verify the amount of aluminum Al (and other minor } \\
\text { species) leached (dissolved) from the solids. This is required, because, some } \\
\text { degree of aluminum removal is required (based on the TWRSO\&UP), but not } \\
\text { too much. Too much removal could create problems with other cations (e.g., } \\
\text { Fe) that could limit the waste oxide loading. Current estimates of the amount } \\
\text { of Al removal are based on limited process test data, and chemical equilibrium } \\
\text { models. Data will need to be obtained to support carrying out an alternatives } \\
\text { generation and analysis (AGA) to determine how much A1 can be removed } \\
\text { before another cation limits the waste oxide loading. Also, establish the amount } \\
\text { of supernate to leave behind so the nitrate cant enhance the ionic strength of } \\
\text { solution allowing more A1 to dissolve. } \\
\text { A process test is needed to verify the amount of Na to be added during the } \\
\text { caustic leaching. This addition of caustic solution will also increase the sodium } \\
\text { concentration. }\end{array}$ & $\begin{array}{l}\text { Perform process test on } \\
\text { representative composite } \\
\text { sample of sludge from } \\
241-\mathrm{AZ}-102 \text { to address } \\
\text { issues raised in the } \\
\text { discussion/evaluation portion } \\
\text { of Table } 1 \text {. }\end{array}$ \\
\hline
\end{tabular}


Table 1. Evaluation of the Base Case Operating Scenario. (5 Sheets)

\begin{tabular}{|c|c|c|c|}
\hline Element & Requirements & Discussion/evaluation & Information needs \\
\hline $\begin{array}{l}\text { Element 3- } \\
\text { Pretreatment } \\
\text { Process } \\
\text { Chemistry } \\
\text { Requirements } \\
\text { (continued) }\end{array}$ & $\begin{array}{l}\text { Type and number of } \\
\text { sludge washes to } \\
\text { meet Waste Envelope } \\
\text { D specifications } \\
\text { (continued) }\end{array}$ & $\begin{array}{l}\text { (Continued) } \\
\text { These should be all the chemical issues related to waste processing. } \\
241-\mathrm{AZ}-102 \text { should meet all other Waste Envelope D chemical and } \\
\text { radiochemical requirements. } \\
\text { The potential also exists for poor settling due to the formation of gels. An } \\
\text { operating range for the process parameters needs to be determined, to avoid gel } \\
\text { formation. } \\
\text { Confirmation that the undissolved solids settle and that they settle in a reasonable } \\
\text { amount of time. } \\
\text { Settling rate data are needed on laboratory scale test for AZ-102. The settling } \\
\text { rates will be measured in a bench-scale settling column for AZ-101. This data } \\
\text { can be compared with the data from laboratory scale test of AZ-102 to estimate } \\
\text { the appropriate amount of time required for waste feed processing. } \\
\text { Confirmation that the baseline retrieval equipment used to mobilize the waste } \\
\text { will work as planned. }\end{array}$ & \\
\hline $\begin{array}{l}\text { Element 4- } \\
\text { Transfer } \\
\text { Requirements }\end{array}$ & $\begin{array}{l}\text { Confirm that the as- } \\
\text { retrieved waste } \\
\text { remains at or below } \\
\text { viscosity of } 10 \mathrm{cP} \text {, at } \\
\text { or below a } 1.5 \mathrm{SpG} \text {, } \\
\text { and at or below } \\
30 \text { percent solids by } \\
\text { volume during the } \\
\text { transfer to the private } \\
\text { contractor. } \\
\text { Confirm that the } \\
\text { selected dilution ratio } \\
\text { using inhibited water } \\
\text { will not form gibbsite } \\
\text { or cause components } \\
\text { in the slurry to } \\
\text { precipitate during the } \\
\text { transfer. }\end{array}$ & $\begin{array}{l}\text { There are limited data for estimating that: } \\
\text { 1) pretreated waste (i.e., after sludge washing) will conform to the physical } \\
\text { measurements around which the transfer process was designed, } \\
\text { 2) the waste feed will remain within the. Waste Envelope D during transfer, } \\
\text { 3) the dilution ratio will not cause excessive gels and other precipitates to form } \\
\text { in the transfer system. }\end{array}$ & $\begin{array}{l}\text { Upon completion of the } \\
\text { desired type and number of } \\
\text { sludge washes, obtain the } \\
\text { pretreated sludge sample } \\
\text { from } 241-\mathrm{AZ}-102 \text { to make } \\
\text { the required measurements. }\end{array}$ \\
\hline
\end{tabular}


Table 1. Evaluation of the Base Case Operating Scenario. (5 Sheets)

\begin{tabular}{|l|l|l|l|}
\hline \multicolumn{1}{|c|}{ Element } & \multicolumn{1}{|c|}{ Requirements } & \multicolumn{1}{c|}{ Discussion/evaluation } & \multicolumn{1}{c|}{ Information needs } \\
\hline $\begin{array}{l}\text { Element 5- } \\
\text { Miscellaneous } \\
\text { Requirements }\end{array}$ & $\begin{array}{l}\text { Physical form of } \\
\text { Tank 241-AZ-102 } \\
\text { contents. }\end{array}$ & $\begin{array}{l}\text { 241-AZ-102 consists of homogenous supernate of approximately 2,940 KL, a layer of } \\
\text { soft sludge of approximately } 394 \mathrm{~kL} . \text { There is no heel/hard pan. } \\
\text { No shimming is anticipated. }\end{array}$ & $\begin{array}{l}\text { No further information is } \\
\text { needed. }\end{array}$ \\
$\begin{array}{l}\text { Shimming Batches 3 } \\
\text { and 4 }\end{array}$ & $\begin{array}{l}\text { No changes to applicable interface control document requirements have been made to } \\
\text { date. }\end{array}$ & $\begin{array}{l}\text { No further information is } \\
\text { needed. }\end{array}$ \\
RL direction & $\begin{array}{l}\text { No further information is } \\
\text { needed at this time. }\end{array}$ & \\
\hline
\end{tabular}


Table 2. Summary of Information Needs.

\begin{tabular}{|c|c|c|c|}
\hline Elements & Information needed & Planned resolution & Sample required \\
\hline $\begin{array}{l}\text { Element } 1 \text { - } \\
\text { Envelope Requirements }\end{array}$ & $\begin{array}{l}\text { Upon performing the desired type and number } \\
\text { of sludge washes, perform analyses on the } \\
\text { resulting sludge to confirm that Waste } \\
\text { Envelope D specifications will likely be met } \\
\text { with } 241-\mathrm{AZ}-102 \text { contents. }\end{array}$ & $\begin{array}{l}\text { After process testing, analyze the } \\
\text { sludge washed sample for the Waste } \\
\text { Envelope D specifications. }\end{array}$ & $\begin{array}{l}80 \mathrm{gm} \text { of sludge washed sample; } \\
40 \mathrm{gm} \text { of original } 241-\mathrm{AZ}-102 \text { sludge } \\
\text { composite. }\end{array}$ \\
\hline $\begin{array}{l}\text { Element 2- } \\
\text { Quantity Requirements }\end{array}$ & Measurement of sludge fraction mobilized. & $\begin{array}{l}\text { After mixer pump operation and full } \\
\text { suspension of } 241-A Z-102 \text { solids, } \\
\text { analyze samples to determine percent } \\
\text { solids, particle density, and chemical } \\
\text { composition as a function of height in } \\
\text { mixed slurry. }\end{array}$ & $\begin{array}{l}80 \mathrm{ml} \text { of } 241-\mathrm{AZ}-102 \text { slurry from } 5 \\
\text { heights in tank. }\end{array}$ \\
\hline $\begin{array}{l}\text { Element 3- } \\
\text { Pretreatment Process } \\
\text { Chemistry Requirements }\end{array}$ & $\begin{array}{l}\text { process parameters for carrying out } \\
\text { each sludge wash cycle including time } \\
\text { versus temperature to reach chemical } \\
\text { equilibrium, ionic strength, and } \\
\text { hydroxide concentration. } \\
\text { - } \quad \begin{array}{l}\text { confirm equilibrium distribution of } \\
\text { chemical species }\end{array} \\
\text { - } \quad \text { amount of } \mathrm{A} 1 \text { in supernate } \\
\text { - } \quad \text { amount of } \mathrm{A} 1, \mathrm{Fe}, \mathrm{Na} \text {, and } \mathrm{Ni} \text { left in } \\
\text { sludge } \\
\text { - } \quad \text { amount of Na removed } \\
\text { - Na added in caustic leach } \\
\text { - } \quad \text { settling tests after washing }\end{array}$ & $\begin{array}{l}\text { Perform process testing to establish } \\
\text { type and number of sludge washes. }\end{array}$ & $\begin{array}{l}100 \mathrm{gm} \text { of sludge washed sample } \\
250 \mathrm{gm} \text { of original } 241-\mathrm{AZ}-102 \\
\text { sludge }\end{array}$ \\
\hline $\begin{array}{l}\text { Element 4- } \\
\text { Transfer Requirements }\end{array}$ & $\begin{array}{l}\text { Confirm that waste meets transfer } \\
\text { requirements. }\end{array}$ & $\begin{array}{l}\text { During process test, confirm that } \\
\text { supernate and slurry meet viscosity, } \\
\text { SpG, percent solids, transfer } \\
\text { requirements. Confirm that remain } \\
\text { within Envelope D physical } \\
\text { properties during transfer. }\end{array}$ & $\begin{array}{l}\text { Performed as part of process test for } \\
\text { Element } 3 \text {, above. }\end{array}$ \\
\hline
\end{tabular}


HNF-3427

Revision 0

\subsection{REFERENCES}

Crawford, T. W., 1998, Data Quality Objectives for TWRS Privatization Phase 1: High-Level Waste Feed Delivery Transfer to Private Contractors, HNF-1805 (PSDQO-10) (To be Issued), Numatec Hanford Corporation, Richland, Washington.

DOE-RL, 1996, TWRS Privatization, Contract Numbers DE-RP06-96RL13308 and 13309, U.S. Department of Energy, Richland, Washington.

Kirkbride, R. A., G. K. Allen, P. J. Certa, A. F. Manuel, R. M. Orme, L. W. Shelton, E. J. Slaathaug, R. S. Wittman, G. T. MacLean and D. L. Penwell, 1997, Tank Waste Remediation System Operation and Utilization Plan, HNF-SD-WM-SP-012, Rev. 0A, Vol. I and II, Numatec Hanford Corporation, Richland, Washington.

Papp, I. G., 1998, Waste Feed Delivery Technical Basis, Volume II, Waste Feed Delivery Flowsheet, HNF-1939-Vol. II, Rev. 0, Numatec Hanford Corporation, Richland, Washington.

Rapko, B. M., and J. J. Wagner, 1997, Caustic Leaching of Composite AZ-101/AZ-102 Hanford Tank Sludge, PNNL-11580, Pacific Northwest National Laboratory, Richland, Washington. 
HNF-3427

Revision 0

This page intentionally left blank. 


\section{DISTRIBUTION SHEET}

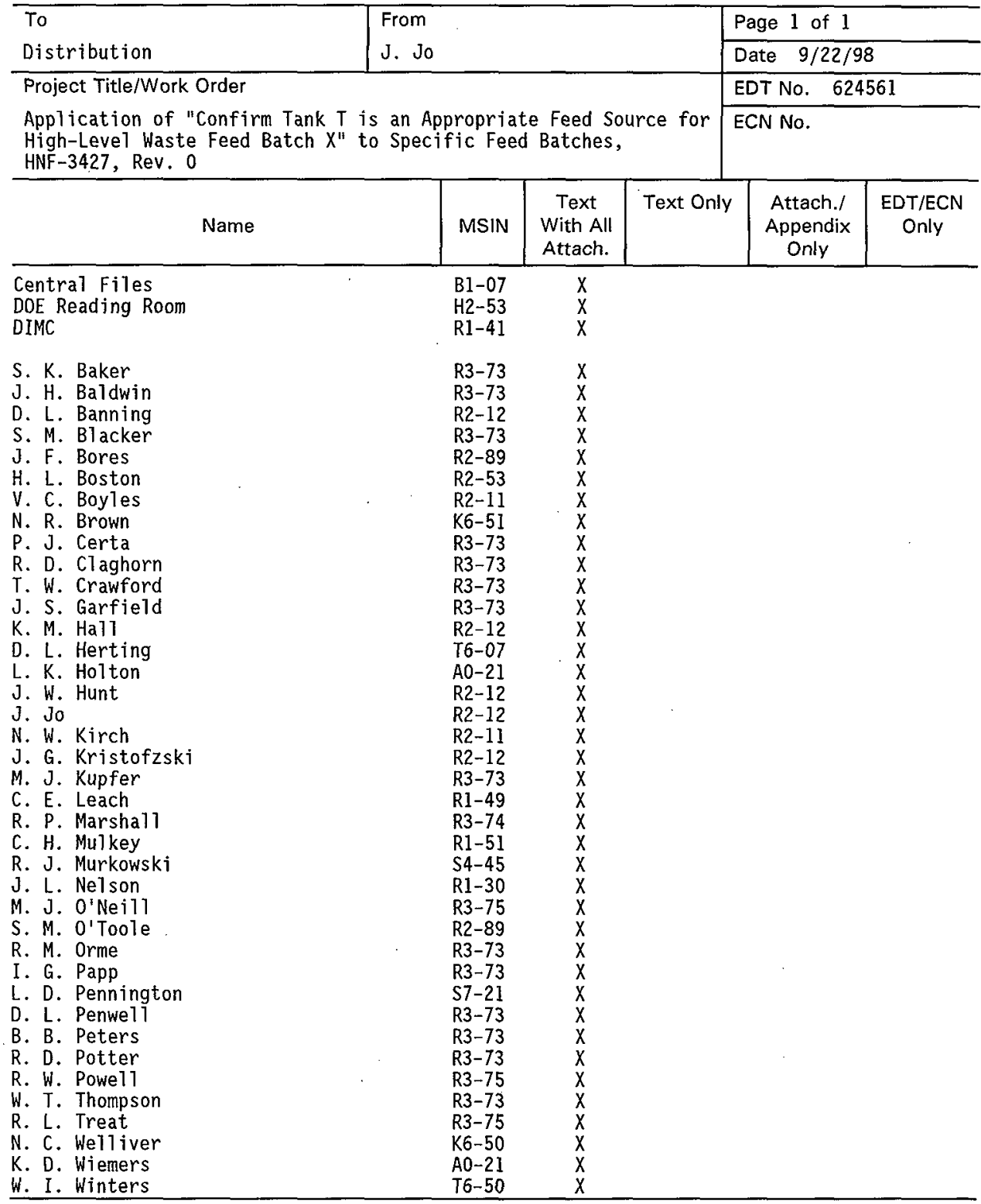

